\title{
DISCRIMINATION OF MEN? NARRATIVES ON TRADITIONAL UNDERSTANDINGS OF GENDER
}

TOVE INGEBJØRG FJELL

University of Bergen

Faculty of Humanities

Department of Archaeology, History, Cultural

Studies and Religion

5020 Bergen, Øysteinsgate 3, Norway
DOI: 10.17234/SEC.27.9

Preliminary communication /

Prethodno priopćenje

Received / Primljeno: 1 July 2015

Accepted / Prihvaćeno: 3 September 2015

This article examines the narratives of men who claim to have experienced female perpetrated intimate partner violence against them, their encounters with public support agencies, the problems that arise from the support workers' expectations of men, and the ways in which gender impacts on the communication between the support agencies and men. The concept of cultural script will form a key part of this analysis.

Keywords: masculinity, gender, child custody, intimate partner violence

\section{INTRODUCTION}

Some men experience intimate partner violence, perpetrated by their female partners ${ }^{1}$, and I have conducted a study on this topic, mainly based on qualitative interviews with male informants. ${ }^{2}$ This article will be discussing how some of these men perceive encounters with public support agencies, and how they are troubled by the lack of recognition they claim to receive, and to some extent, the discrimination they claim to suffer on the basis of gender. I consider this part of the interview material to constitute sub-themes in the informants' self-presentations, and informants' descriptions of public support agencies and their traditional understanding of gender form key parts of their narratives. The narratives about child

\footnotetext{
1 In this context, "partner" refers to a current/former spouse or cohabiting partner.

2 I have previously examined issues concerning violence against men in Fjell 2012, 2013 and 2014. The topic discussed in this article has been published in a broader context in Fjell 2013, which is a book written in Norwegian.
} 
protection officers, family support workers and court officials exemplify what the men refer to as prolonging the abuse beyond the break-up of their relationship: Partner violence was claimed to have been committed by the female partner before the break-up, and continued by the partner, as well as the authorities after the break-up. The narratives in this article will be referred to as narratives concerning violence against the male informants.

Research on partner violence normally differentiates between different forms of abuse, for instance between physical and psychological violence. Physical violence refers to more or less severe instances of punching and pushing, while psychological violence involves verbal abuse, social and economic isolation, jealousy (including of family, friends, pets), threats to hurt or kill, and threats to leave, divorce, have an affair, ruin personal belongings, sabotage court proceedings for custody visitation arrangements, and to speak ill of one's partner vis-à-vis the child or children etc. (Pape \& Stefansen 2004; Sogn \& Hjemdahl 2010). ${ }^{3}$

The aim of this article is to shed light on problems claimed by the men surrounding the support agencies' expectations of them. This article will look at crossover ${ }^{4}$ incidents in greater detail, i.e. incidents that break with the norm for gendered behaviour (Hjemmen, Dalgård \& Graff-Iversen 2002:280; Sogn \& Hjemdal 2010:33). Research questions are: How is gender brought into play in the communication between support agencies

\footnotetext{
${ }^{3}$ Other categorisation systems involve differentiation between physical violence, material violence, economic violence, sexual violence and psychological violence; or between the following five types of violence: a) common couple violence (situational couple violence), which has low prevalence and is less serious, and may involve either partner in the role of the abuser or the victim; b) mutual violent control, which is rare and involves both partners being violent and controlling; c) patriarchal terrorism (intimate partner violence) i.e. "classic" abuse, which is far more serious and escalating, and is most often perpetrated by men against women; d) violent resistance, which is primarily exercised by women who fight back in response to intimate partner violence perpetrated by a violent and controlling individual; and e) separation-instigated violence, which occurs in connection with the break-up of a marriage or cohabiting partnership with the abuser most commonly being the person abandoned (Sogn \& Hjemdahl 2010).

${ }^{4}$ In this article the crossover category includes men who suffer "typical female violence".
} 
and male victims of partner violence? What patterns of understanding and cultural scripts are claimed available regarding men at risk of intimate partner violence?

The concept of cultural script will form a key part of this analysis (Grøvdal 2012:215 ff.; see also Baker 1997). A cultural script produces patterns of understanding that point in a certain, often stereotypical, direction and limits latitude: Supported by the sociologist Phyllis L. Baker's research, the criminologist Yngvil Grøvdal maintains that there is only a single cultural script available to female victims of intimate partner violence: to leave the man and stay away from him. If the woman fails to go down this route, she will be at risk of losing her credibility, e.g. vis-àvis the support agencies and the judiciary (Grøvdal 2012:215 ff.; Baker 1997). Phyllis Baker maintains that this cultural script provides little latitude, which is why we see a number of specific opposition strategies, like staying put with the abuser (Baker 1997). In a simple cultural script for partner violence, the man is presupposed to be an abuser, the woman a victim, and if the woman exercises violence, it is believed to be an action of resistance in response to violence from a partner. How may the concept of cultural script aid understanding of the experiences of men presented in this study?

\section{METHOD AND MATERIAL}

The study is primarily based on qualitative interviews with Norwegian men who claim to have been the victims of intimate partner violence. The informants are over 20 years of age and live or have lived in a heterosexual relationship. I advertised the project on a website run by Reform, a resource centre for men, and the men responded and got in contact with me. ${ }^{5} \mathrm{~A}$ qualitative selection will never be statistically representative, and this particular group of men is not representative of all men who suffer intimate partner violence. However, the interviews may give an indication of the problems that exist within this little-researched field. I interviewed eleven

\footnotetext{
5 www.reform.no
} 
ethnic Norwegian males. All the couples involved had children, and all the men had repeatedly been the victims of partner violence over a period of time ${ }^{6}$.

The interviews focus on the informants' descriptions of specific episodes of violence, and they include a number of first-person personal experience narratives, reports of incidents and the informant's interpretation of them (cf. Stahl 1977). Given the topic, there will always be reason to ask whether the incident referred to has really happened, or if the narrative forms part of a vendetta against an ex-wife, or suppression of what really took place. I have no way of knowing for sure whether my informants' narratives provide a true account of what happened. I was not present when the incidents took place, and I have not talked to their female partners to get their version of the same events. Neither have I talked to police officers who were called to attend, to family members who witnessed the violence, or to the child protection and family support officers involved. The informants' narratives will also, to varying degrees, be influenced by the presence of a third person: Self-presentations are coloured and shaped by the perceptions

\footnotetext{
${ }^{6}$ Eight informants had ethnic Norwegian partners, two had partners from another European country, while one of them had a partner from a non-European country. Seven of the men were in their 40s while one was in his $20 \mathrm{~s}$, one is his $30 \mathrm{~s}$, one in his $50 \mathrm{~s}$ and one in his $60 \mathrm{~s}$. Seven had been married to the woman they refer to in their interviews, while four had been cohabiting partners. Only one of the informants was still living with the abusive partner at the time of the interview. Ten of them had ended their relationship with the abusive partner, and four of them had re-married or had moved in with someone else. Six of the men had been married to or lived with the abusive partner for less than five years, one had been married to/ lived with his partner for less than ten years, one for less than 15 years, two informants had been married to or lived with their partner for less than 20 years, while one had been married for less than 25 years. The informants' level of education ranges from graduates to secondary school-leavers. Five of the men had either completed or started a degree course. Intimate partner violence is often associated with intoxication in general, and specifically with alcohol (cf. Hydén 1995, 161; see also Flanzer 2005). Intoxication was a topic referred to in four of the ten interviews, either affecting the informant or his partner, either during the abuse or generally in their life together. Two of the men talk of intimate partner violence at the hands of more than one partner, while nine of them were the victims of a single partner. All informants come from towns and villages in South Norway. The interviews were conducted in the period $2009-2013$.
} 
of reality which are disseminated by the media and by research (Pripp 2009:43 ff.).

The informants' narratives are far from unambiguous, they may be interpreted in multiple ways. One may differentiate between having observed or witnessed something on the one hand, and the individual's personal attitudes on the other (Kvale 1995:158-159; see also Natland 2006:49-50). I do not approach the informants' narratives as if they were witness statements, and I realise that other people who were present, may have a completely different understanding of what took place. Why was one of the men almost set alight by his wife? Had he done or said something beforehand which made her angry? Not according to him, but perhaps his wife would have told the story in a different way. What made another informant's wife say, in front of their children, that she hoped her husband would drown, so that at least they would receive the life insurance money? Had he said or done something to make his wife lose control? And not least: did she say this? Did one of the child protection officers shout at the top of her voice to one of the men? In other words, the narratives are not considered to be empirically correct descriptions of specific situations, but they convey the men's subjective account of their own experiences.

When I first made my appointments to interview the informants, they were very willing to talk about their experiences in great detail. Anonymity was important to them, and out of concern for them and their close circles I will not describe them individually, I will only provide general information that refers to the group. "The answers provided by one person in an interview, may be harmful to a third person - or a third person may feel that they have suffered injury" (Alver \& Øyen 1997:104). Such third parties may be the informant's children, former partners, or relatives who have never asked to have their family history made public. Parts of the material are therefore sensitive in that they have a strong personal association with the narrator as well as with the people he brings into his narrative.

7 Steinar Kvale distinguishes between the terms informant and representative, which I fail to find useful in the context of this study (Kvale 1995:58 - 159.) 
In our culture, men as a group are not marginalised, weak or vulnerable, but the incidents referred to in these interviews, make the informants vulnerable. For this reason I have chosen to refrain from providing indepth portraits of the informants ${ }^{8}$. In consequence, my account is somewhat restricted, in that the desirable "thick descriptions" inevitably are thinner and provide less of a context than what would have been required for a less sensitive research topic. ${ }^{9}$

\section{ARE WOMEN AT GREATER RISK OF INTIMATE PARTNER VIOLENCE THAN MEN?}

The research available has come to different conclusions with respect to whether intimate partner violence against men is as common as intimate partner violence against women. The sociologist Murray A. Straus points out that different methods and types of sources may provide different answers to this question (Straus 2005). Most partner violence studies look into women's experiences only (e.g. Alsaker 2008; Lundgren 2002; Pizzey 1980), but some of those that do study men's experiences, conclude that

\footnotetext{
${ }^{8}$ I have anonymised the informants as follows: All names of people and places have been changed, and there is no link provided between the informants' name and their age, social background and educational background. The age of children is given in broad categories ("below school age", "school age"), and all dialectal expressions have been removed. In some contexts, especially with respect to conflicts that involve children, the men are referred to as "he" or "the informant".

9 The project has been approved by the Norwegian Social Science Data Services (NSD), and I have followed the guidelines published by the National Committee for Research Ethics in the Humanities and Social Sciences (Research Ethics Comittees 2010), particularly with respect to anonymisation (Alver \& Øyen 1997; Alver, Fjell \& Øyen 2007). With one exception, all interviews were transcribed verbatim in their entirety. The informants have received the transcripts of their interviews and have been given an opportunity to make changes or additions. They have also been made aware that the transcript will be used for research purposes. I have used a number of other sources for this study, such as media reports of intimate partner violence against men in the period 2009-2011. Under the auspices of Norwegian Ethnological Research a questionnaire on this topic was distributed in June 2011 (questionnaire no. 61). I have also conducted interviews with staff at two refuge shelters.
} 
intimate partner violence perpetrated against men is not an insignificant problem (Helweg-Larsen \& Frederiksen 2008; Hansen 2012; Pape 2003; Selin 2009).

Most research on intimate partner violence maintains that women are at greater risk, and that consequently women should remain at the focus of our attention. However, if we look at all violent crime, men are at greater risk than women when it comes to reports of threats, actual bodily harm and assault. If we look at domestic abuse and sexual offense specifically, women are over-represented in the statistics (Statistics Norway 2010:22-23). However, this cannot lead us to the conclusion that women are at greater risk of intimate partner violence than men. First, the statistics include only incidents which are perceived to be serious enough to warrant reporting, i.e. only a small portion of the incidents that actually occur. Second, most research focuses on intimate partner violence against women (e.g. Lundgren 2002; Alsaker 2008; Valvo 1981; Amundsen et. al. 1981) so these studies cannot be used to prove that women are at greater risk than men. Third, until 2010 the refuge shelters (in Norway) would almost exclusively accept only women. Consequently, not even the experience accumulated by the refuge shelter movement over the last three decades can be used to prove that women are at greater risk than men.

However, some studies have been published which also look at male victims, and these works are therefore better suited to answer the question of the degree to which men are at risk of intimate partner violence. Some of these are quantitative studies carried out in Norway, and they indicate that men are just as much at risk as women, but that the abuse they suffer often tends to be psychological violence or physical violence of a less serious nature (slaps to the face, kicking), rather than incidents with outcomes that require medical attention or which are fatal (Haaland, Clausen \& Schei 2005; Pape 2003; Pape \& Stefansen 2004; Pape 2011). ${ }^{10}$

\footnotetext{
10 The abuse of women tends to take the form of more severe physical violence than the abuse of men. Also more women than men are murdered by their partners: The Norwegian homicide statistics show that 66 women and 12 men were killed by their partner or expartner in the period 2005-2014 (Kripos 2014).
} 


\section{"WHY DO THEY NOT BELIEVE ME?"}

There are currently a number of agencies that offer support to people who have been the victims of violence. ${ }^{11}$ The remainder of this article will focus on the informants' narratives and assessments of their own experience of lengthy negotiations about child visitation rights. The latter is currently a hot topic in Norwegian society, both with respect to parents' visitation rights and what is "best for the child". ${ }^{12}$ In recent years, there has been much public debate about the parents' unwillingness to co-operate, visitation boycotts, mothers' attempts to shield children from a violent father or a father who sexually abuses his children, fathers' attempts to prove that the mother's initiative is all about increasing the amount of child support and therefore ultimately about financial benefit, and mothers' attempts to prove that the father is seeking extended visitation rights because he wants to reduce the amount of child support payable and is therefore also ultimately about financial benefit.

For some, the break-up of a relationship does not bring an end to conflict. The disputes in this material are primarily about child visitation rights. After a break-up, ex-partners tend to spend little time together, except in meetings with the support agencies and when children are being collected or brought back home. These are situations that may be difficult to handle if the conflict level is high. Some experience physical abuse in these situations but the informants refer more frequently to psychological abuse, like the calling of names in the street, the spreading of rumours and

11 There are family support offices, emergency shelters, emergency phone lines, accident and emergency hospital departments, police, emergency mental health departments, conflict resolution counselling services, support services for victims of crime, and the Criminal Injuries Compensation Authority (cf. Sogn \& Hjemdal 2010:44 ff.) In addition, the Centre for Sexually Abused Men offers support for men who have suffered sexual abuse at the hands of male or female perpetrators. In the spring of 2010 a new website was launched - http://utsattmann.no - specifically for boys and men who suffer sexual abuse. The website is run by a network, utsattmann.no, with support from the Norwegian Ministry of Children, Equality and Social Inclusion.

12 The statement concerning "what is best for the child" is found in Article 3 of the UN Convention of the Rights of the Child (the Children's Convention) (Save the Children 1993, pp. 39-50). 
the filing of police reports which the men themselves claim to be false allegations that constitute acts of revenge by the ex-partner. If the conflict level is high enough, the family support agency will be brought in, and if there is suspicion of child neglect, the child protection agency and the courts will be alerted. ${ }^{13}$

Paul was one of the informants who experienced problems with visitation rights after the break-up of his marriage. At first, a solution was sought through mediation, but the case ended up in court. He demanded access to his children, who lived a couple of hours away, but claimed that he was not allowed to decide for himself where he would spend time with his children. His ex-partner did not want him to take the children to his own home, nor did she want him to meet up with anybody else while he had access:

Informant: "The first year after we broke up I had to travel into town twice a week and see them there. To begin with, I would have to walk around town with them. I had nowhere to go. She would not allow me to meet up with anybody else whenever I had the kids."

Because Paul initially was unable to meet up with anybody else when he was with the children, he spent most of his time with them in various shopping malls and play parks. After a year he managed to negotiate entitlement to see them in the home of an elderly relative who lived near the children and their mother. Paul felt that the family support agency provided no assistance during the parental mediation process, and the arrangement was negotiated in court.

Overall, Paul's experience of the family support agency was quite negative. He felt that he was neither acknowledged nor believed at any point in the marital mediation process as the couple and their mediator sought to

13 The informants with under-age children referred to a number of encounters with this part of the support network. Their experiences were generally negative. Their accounts and opinions of the support agencies share a number of similarities with the findings reported by researchers Fritz Leo Breivik and Kate Mevik in their study of women's /mothers' encounters with the judicial system in connection with child custody cases (Breivik \& Mevik 2012). 
make the relationship work between the two partners. On a few occasions he had bruises to his face when these sessions took place. He said that he never raised the fact that he had been slapped with any of the family support workers, and no-one asked him about it. It was not until the relationship had ended, and the parties attended an appointment about child visitation rights, that he himself raised the matter. To him, having the manifestations of violence ignored felt worse than the actual acts of abuse:

Informant: "That's really what hurts the most. After we broke up I told them what things had been like - I told the person we had been seeing. She told me that surely, it wasn't as bad as all that."

Interviewer: "That's rather a peculiar response."

Informant: "And then ... It really has been very hurtful ... Then I was able to talk to someone else at the family support agency. And that was completely different, so much better. She believed what I was telling her. Came up with constructive explanations. Showed some understanding. But it was really hurtful to be brushed off by the person we had been seeing so many times. I had been sitting there with bruises to my face from her punches, not daring to say anything about it ... and then you're told that surely, it wasn't as bad as all that. There were other things she simply refused to believe. She told me straight to my face that she refused to believe me. So ... that's really what I felt was the most hurtful."

Paul eventually found the understanding he was looking for, but kept coming back to the one case worker who refused to acknowledge him, ask questions about the bruises to his face, or believe him when he told her what had been happening. The fact that Paul felt he was not believed when he talked about being punched, may be seen in connection with the difficulty of associating a woman with abusive action: A violent woman fails to comply with norms of gendered behaviour, and there are very few appropriate patterns of understanding. Paul's account conveys the support agencies' rigid perception that the perpetrators of intimate partner violence are male and that the man is "the stronger gender", while the victims of intimate partner violence are female and that women are "the weaker gender". 


\section{"WHY DO THEY BELIEVE EVERYTHING SHE SAYS?"}

A number of the informants mentioned a recurring pattern - women invariably appear to be believed or acknowledged while there appears to be little chance of a woman being seen as anything but a victim. Many interpreted this to mean that support workers generally fail to question claims put forward by women and to consider them critically. One of the informants felt that his wife was allowed to pretend that the children were ill, without anyone querying her assertions. Whenever the husband talked about his children with support workers, he would describe them as caring individuals who were doing well at school, whereas his ex-wife and the children's mother would present them as dysfunctional and suffering from specific diseases. One of the children went to see a doctor who refuted one of the mother's claims, but nevertheless, the disease was never removed from the case documents:

Informant: "It was confirmed that the child is not suffering from this disease, but nonetheless, the mother tells the child protection officers that he has it, and they write it down in their reports and consider it to be a fact. "The child required special attention." Again, it sounds like little niggles, but the fact is that the kids are really good. It's a miracle that they are as on the ball as they are. Really good and really clever, resourceful kids. One of them is top of his class, the teachers tend to say. The very best. A really responsible attitude. But when the child protection officers look at the case, they are told by the mother that he is socially dysfunctional. That he suffers from a number of specific diseases, is aggressive and violent. The child protection people want to send him on an anger management course. And then she brings them along to a psychologist for treatment because they're supposed to have been abused by me. She claims they have suffered mentally because they have been the victims of abuse. In my opinion, that treatment amounts to child abuse. Treatment for incest, which has never taken place."

He stated that his child had not been given medication for the disease, but the case documents nevertheless continued to refer to the child as suffering from this disease. According to the informant, this had no bearing on the child protection officers, as information provided by the 
child's mother would not be removed and therefore continued to exist as facts in the case. The counselling that the children received after allegedly having suffered sexual abuse, is a slightly different matter. According to the informant, the abuse was just as much a figment of the mother's imagination as was the diagnosis of one of the children. But while it is relatively simple to prove that a child does not suffer from a specific disease, it is harder to refute allegations that a child has been the victim of sexual abuse.

Other informants talked of similar episodes; their ex-wives were reported to have made allegations which the child protection agency had accepted without question. Some of these accounts are coloured by years of conflict and are voiced in an aggressive tone. One of the informants felt that since his break-up with the mother, one of his children was faltering and he wished to raise the matter with a child protection officer:

Informant: "I made an appointment with a child protection officer for a Friday, so that I could talk the situation over. I told my wife. But then she went to see the child protection officer the day before and served up her story. That was her all over, throughout our life together: she was always one ahead. Whatever the case might be. When I turned up at the child protection agency on the Friday, I was introduced to a case worker, who was later promoted to head the child protection department in a town nearby. She sat with her legs stretched out in front of her, one across the other - her hands folded across her chest. The only thing she said was: 'Have you been hitting her?! Why did you do it?! Have you been hitting her?! Have you been hitting her??!!' She was shouting at the top of her voice in a bout of rage. So I said: 'If I had, then that would be a matter for the police, although these are groundless allegations. But as far as I know, you don't work for the police, surely you're a child protection officer, aren't you? I came here to talk about the children.' She repeated herself, and refused to initiate a conversation about the children unless I confessed to having battered my wife. So I had to tell her that [...] 'Well, in that case I have no business here.' For I can't confess to something that isn't true [...] just because I'm worried for my children. She wanted to use this to pressurise me into confessing to what my wife had told her the day before [...] It was so bad that the lady who headed the child protection department at the time [...] in a meeting with two representatives of the outpatients clinic for the Department of Child and Adolescent 
Psychiatry [...] she, as the head of the agency, openly apologised for her officers' conduct and that they had failed to take me seriously before. The two case workers who had been dealing with us were both present and were sat staring at the table."

According to this informant, he found himself in a deadlock, and his account bears witness to this situation: He tried to help his child, but before he could, his ex-wife complicated the situation, and so he encountered an unprofessional case worker who failed to provide assistance, even if in the aftermath the agency had to apologise. Did the child protection officer really shout at the top of her voice in a bout of rage, and did she really behave quite as unprofessionally? I cannot possibly give the answers, but in this context the point is that the informant perceives the situation in this way, as having been exposed to unnecessary execution of power, and gives his account accordingly. His interpretation is that the child protection officers consciously elected to back a winner to allow them to achieve something. He maintains that they broke him down mentally, to the extent that he 'disappeared' and became a non-problem for them, and that in his case, they chose to back his wife's version of events, crowning her the "winner".

The two latter cases showcase that the support agencies struggle to respond to the fact that men may be victims in a high-conflict context. Is this reflected in custody settlements? There seems to be clearly significant differences between custody settlements in and out of court: Child custody cases that are settled in lower courts (any of the municipal courts or the District Court) are more likely to end up with the father getting custody than if the matter is settled out of court. A study shows that if the courts are not involved, father is awarded custody in only 20 per cent of cases, which means that this is an area of society which is heavily affected by gender segregation (cf. Holter 2003:166-167). Other studies show that women may fail to be heard when it comes to child custody disputes settled in court. A study of women's encounters with the judicial system in child custody cases shows that women are far from ever-successful; this is considered to be associated with the abandonment in 1981 of the maternal presumption (mother's priority parental right) and with the work to achieve gender equality in law (Breivik \& Mevik 2012:118 ff.) When the custody issue is settled by the judiciary, the lower courts tend to award custody to the father 
more often than the higher courts (the Court of Appeal), where custody is awarded almost equally to mothers and fathers (see also Report to the Storting no. 8 (2008-2009) pp. 11, 80). ${ }^{14}$ Another study shows that most children who live permanently with father, are teenagers. In other words, younger children more often tend to be living with the mother than with the father (Jensen 2003; see also Skjørten 2005:41). The sociologist An-Magritt Jensen poses an interesting question in one of her studies: Why is the group of children in father's custody growing, albeit still small? She suggests a number of contributory factors, such as policy changes that strengthen fathers' legal rights as parents, cultural changes like greater practical child care experience among fathers, and increased attention afforded to child custody issues in general and to the weak position of fathers in particular (Jensen 2003).

My study includes not only cases that have gone to court; it discusses men's encounters with a number of different agencies. Even in cases where the father eventually has ended up with parental responsibility and

\footnotetext{
${ }^{14}$ A study of 129 child custody cases brought before the Court of Appeal in the years 19982000 , shows that in 44.2 per cent of the cases, the courts found in favour of father, allowing the children to live permanently with him, while they found in favour of mother in 48.8 per cent of the cases. In seven per cent of the cases, the siblings were split up and allocated to different parents. However, the lower courts found, in the same cases, in favour of father in 54.7 per cent of the cases and in favour of mother in 39.5 per cent of the cases. In 5.4 per cent of the cases the siblings were split between the parents, and in 0.8 per cent (one case) the case did not involve permanent residence (Skjørten 2005, 41-42; see also Skjørten 2004). The child visitation and contribution survey 2002. Documentation and tabular report (2004) shows that the distribution of parental responsibility is disproportionate: The mother reports to have sole parental responsibility in 53 per cent of cases while the father has sole parental responsibility in four per cent of cases; the parental responsibility is shared in 42 per cent of cases (Sætre 2004; see also Skjørten 2005:41). Another child custody study focused on cases that were settled out of court, but to which public agencies had contributed to some of the decision-making. In this study, 76 per cent of the children were in their mother's day-to-day care, while twelve per cent were in their father's day-today care; the parents shared the parental responsibility in ten per cent of the cases, while two per cent of the children lived with neither of their parents (Moxnes 2001:108). These latter figures show that the children of divorced parents most often live with mother, when case is solved out of court.
} 
visitation rights, the informants criticise the way in which they perceive to have been treated. A number of them draw a picture of support agencies that favour women and mothers, so that a man can be awarded custody of his children only after lengthy negotiations and burdens of proof. This is not necessarily because the support agencies consciously select a "winner", neither does it need to be empirically correct if we look to Skjørten's and Breivik \& Mevik's studies.

However, the male informants in this study feel that the support agencies have a traditional take on gender, so that women and mothers are presumed to be best suited to take care of the children, whereas fathers, often undermined by police reports lodged by the abusive partner, are easily redefined into potential abusers, which excludes them from being considered as potential care providers. The informants' criticism focuses on their experience of being suspected and ignored within their own lives - an experience which is reinforced by abusive female partners who appear to pass under the agencies' radar, because the role they play is too improbable.

\section{INCEST - FOR REAL, OR ALLEGATIONS AS PART OF A STRATEGY?}

Reports of incest in connection with marital break-ups and custody disputes are referred to as "the nuclear bomb of child custody battles", and they are not an uncommon feature in child custody negotiations (Cook 1997:62 ff.). ${ }^{15}$ Kristin Skjørten's study reviewed the legal practice employed in the 129 child custody cases that were brought before the Court of Appeal in the period 1998-2000. Violence among family members and/ or abuse of children was involved in 23 per cent of the cases, and ten cases referred specifically to the sexual abuse of children. Skjørten emphasises that allegations of abuse in child custody hearings may vary from being completely unfounded to involving serious abuse, and that the credibility

15 Plauborg \& Helweg-Larsen's report on intimate partner violence against men in Denmark raises the topics of incest allegations and discrimination suffered at the hands of public agencies (2012:41-47). 
of allegations of abuse must be considered in each individual case (Skjørten 2004:168).

Every now and again the media point out that some men may have been the victims of unfounded allegations of incest, and that the long-term effect of such allegations may be irreversible. ${ }^{16}$ In April 2011 one newspaper published a seven-page spread about a man who was accused of incest against his six-year-old son. The allegation was made by his ex-wife during custody negotiations (Mjelva \& Nygard-Sture 2011). The man could still remember the smell of the lawyer's office on that day in April 2006, when he learnt that he had been reported to the police for sexual abuse: "I was stunned. I couldn't move. It felt as if someone had put a 400-kilo backpack on my shoulders. I'm not sure how long I was sat there, but I was out of it, quite simply out of it" (Mjelva \& Nygard-Sture 2011). This man was found not guilty, but further allegations were made, which were taken seriously by staff at the Department of Child and Adolescent Psychiatry and by child protection officers. Further court cases ensued, and the allegations were again disproved. Yet he thinks he will never be able to feel completely exonerated. He is now anxious in any situation that involves children, he worries about running into people he knows in the supermarket, and he has given up the fight for custody of his son: "I would much rather have been accused of murder, or mass murder for that matter, than something like this" (Mjelva \& Nygard-Sture 2011).

Some of the informants in this study have experienced allegations of incest against their own children. They maintain that this has never taken place, that these are unfounded allegations that form part of their ex-partner's fight for sole custody of the children. Determining whether incest has taken place may be difficult for the agencies tasked with investigating such claims. One of the informants spent several days in court over child custody. He had been reported for incest after he had filed for divorce. According to the informant, the ex-partners' willingness to

\footnotetext{
16 See Gabriella Nilsson's thesis on changes to the incest discourse from 1982 to 1996. She suggests that the significant rise in the number of incest allegations, may have been caused by the fact that a witch-hunt against individual men who abuse children, was considered acceptable, while a witch-hunt against men as a group, was a more difficult matter (Nilsson 2009:89 ff., 157-158).
} 
cooperate consequently suffered, and it proved increasingly difficult, and eventually impossible, for the informant to maintain contact with his child. However, even if things were difficult for him after the break-up, with legal proceedings, serious allegations and lack of contact with his child, he felt that life was better than before:

Informant: "Things improved a lot for me afterwards, because I got much of my freedom back. Being a human being who can breathe without being anxious about making mistakes all the time."

He explained the incest allegations by saying that the less his wife knew about what actually happened when he spent time with their child, the more she started fantasising. When he was first served the charges, he wondered whether his wife was cruel, or whether she suffered from misconceptions that were not anchored in reality. When the experts failed to support his wife, he felt relief. He was far less critical of the judiciary than other informants who found themselves in a similar situation, and rather than aggression, he conveyed a sense of deep despair over having been stopped from having contact with his child. He understood that incest cases are complicated, and was relieved that the legal system had ruled in his favour in the end.

Other informants took a more confrontational attitude vis-à-vis the judiciary. Some wondered why the support agencies took their ex-partner's repeated allegations seriously, apparently without asking whether these allegations might form part of the ex-partner's strategy in fighting her own case, and the men responded in different ways to allegations of incest or the idea that such an allegation may be put forward. One of them had been worried that such an allegation might arise, and took precautions. During the first hearing he asked his wife for a confirmation in writing that she had never suspected him of incest. Her lawyer had been shocked and asked what "sort of madness" this was. He had answered that this was not madness at all, that all he needed was a confirmation and then they could move on. At the time, he had considered his wife to be perfectly capable of accusing him of incest. He was later accused of all manner of things, except incest.

Another informant kept the intimate partner violence a secret, but not the incest allegations against him. Only a handful of people knew about the 
violence, while "everybody" knew about the incest allegations, because it came to court, and because the ex-wife allegedly had told the informant's employer, neighbours and mutual friends about it. Old friends cut off their friendship with him, they stopped talking to him, and he stopped phoning them. He said that when he decided to rent a flat, his landlord approached him a while after the tenancy agreement had been signed, and told him that she had heard some very unfavourable things about him. She had told him that had she not come to know him before she heard the rumours, he would never have been given the tenancy. Members of his ex-wife's family are alleged to have threatened him on the phone and in the street, saying that they would "get him", "crush him" and "ruin his life." He said: "It's so upsetting. The hate is so extreme. The extreme hatred has broken me."

\section{PUBLIC SUPPORT AGENCIES-PROLONGING THEABUSE?}

Most of the informants who had been in touch with a family support office, the child protection agency or the judiciary maintained that they needed to be resilient and that they felt their chances of being believed were minimal. This experience helped form their perception that Norwegian officials will tend to believe in women's versions of family disputes and take little account of men's perceptions of reality. ${ }^{17}$ As already pointed out, this is not entirely correct, empirically speaking, as research shows that there are clear differences in settlements in and out of court: Children tend to live with mothers when the case is solved out of court, with fathers when the case is solved in lower court, and custody tends to be equally awarded in a court of appeal (Skjørten 2004; Skjørten 2005; Sætre 2004; Holter 2003; Moxnes 2001).

One of the informants had been fighting for a long time to gain visitation rights, and he had not seen his children for years. When the case was heard by the court, they found in his favour. A visitation agreement

17 The ethnologist Simon Ekström's study entitled Trovärdighet och ovärdighet. Rättsapparatens hanterande av kvinnors anmälan av våldtäktsbrott Stockholm 1946-1950 shows that women who have been the victims of rape or attempted rape, have to present the abuse in a special way in order to be believed (Ekström 2002). 
was drawn up with dates and times. But this proved not to be enough, in the interview he said:

Informant: "On the way out of court, she came up to me and said: 'Don't you go get any bloody ideas.' 'What?' I said. No, she had agreed to the settlement simply to get out of the courtroom. 'But don't get any bloody ideas about getting to see the kids."”

According to him, things turned out as she predicted; he was never allowed to see the children. On a different occasion he had reached yet another settlement with his wife, based on her work shift rota, to accommodate her working hours. A few days later she phoned up and left a message saying that there would be no visitation after all, for she had just changed her work rota. The agreements collapsed, one after the other. According to the informant, none of the public support agencies intervened in this situation, and nobody interpreted this to mean that his ex-wife was putting obstacles in his way. He wondered whether any of the support workers would have objected if he - as a man - had made a similar move and prevented the children's mother from having contact with them.

George is one of the informants who feels let down by the support agencies. His interpretation is that, as a man, he routinely fails to be believed in connection with his custody case, that "women in Norway can do whatever they want", and that being male is a handicap in Norwegian society. George was married to a woman from a non-Western country, and he is very bitter that she filed for divorce on the third anniversary of her indefinite leave to remain in Norway, and that she referred to their child as "my passport". After their break-up, conflicts would arise in connection with picking up or bringing home the child, and at a later stage they ended up in court over the custody issue. George's version is that he and the child had spent some good times together, but whenever the time came to go back to the mother, the child would throw a tantrum, refuse to go home and cry a lot. As a result, the child's mother wanted to be present whenever George was with the child. He refused, and on one occasion he is alleged to have taken her by the arm and pushed her out of the car when she wanted to join them. After this incident, he was reported to the police and lost his visitation rights. He was later told that his wife had acquired a personal safety alarm. George 
failed to understand how his wife had managed to get a visitation ban and acquire a personal safety alarm. It was becoming increasingly difficult for him to spend time with his child, so much so that he could no longer bear to have ordinary contact, but elected instead to await the court's decision. George was convinced that "the child was not properly cared for at home", a conviction he conveyed to the child protection agency. But according to George, his ex-wife "ran rings round" the child protection agency:

Informant: "Women never need to prove anything! Women need only come up with allegations! That's how it works, and we know that from a lot of areas. [...] The court's been told that I'm just a horrible person and shouldn't have had a child. And as for me, I feel that I can't take any more. I have reached a limit. I feel that when I'm talking to you right now, the despair keeps surfacing."

He felt that the support agencies never doubted his ex-wife's allegations, and he found that only her version of events were considered when the agencies looked over this specific case. This ethnically Norwegian man portrayed Norway as a country where men suffer gender discrimination and have little say in disputes over custody. Like a few of the other informants he considered moving away from Norway, which in his opinion had nothing to offer him, and where he had failed to be believed.

Others report similar encounters with the support agencies, where allegations put forward by women were believed and never queried by child protection officers or in court. What brought the following informant to his breaking point, more so than the domestic abuse he suffered in his marriage, was the sense that the state carried on the abuse and became his adversary rather than his supporter. He felt that the state prolonged the abuse perpetrated by his ex-wife, specifically through frequently recurring child protection investigations:

Informant: "I'm really quite helpless as it's me against the state. I feel I have no guarantee of due process. It's universal. There are so many agencies involved in each case, that things grow out of hand. There is the child protection agency, and then there are umpteen psychologists, there are [...] all sorts of other random coaches and therapists and experts. Many are doing a good job but the mother clearly excels at finding the rotten apples, so to speak - the really 
prejudiced experts who bulldoze everyone else. If I complain, go via the normal channels to voice my grievances, to the Board of Health Supervision, or if I complain about the conduct of the child protection officers [...] normal, obvious entitlements like freedom of information and disclosure of documents in child protection cases, then all I will achieve is to antagonise the entire establishment. Obvious things that you would think were simple matters of routine, like disclosure of documents, instead they become appeal cases that take years to resolve."

He felt that he was living in a Kafkaesque world, and that he had no recourse to Norwegian authorities. He found in theory the rules and regulations to be fine, but in his experience, they did not apply to him - as a male. He had found that rules he thought would support his case, were constantly negated by exemptions and discretionary judgments. He was surprised and upset that a civilised and democratic society could allow him to suffer such a plight:

Informant: "If someone had told me ten years ago, before we split up, that the things that have happened could happen in Norway, I would never have believed it. It never occurred to me that it might be problematic for the kids to maintain contact with their dad after we were divorced."

He was also puzzled by the potential consequences of false allegations. He fully appreciated that public agencies need to take such allegations seriously the first time around, and the second time and perhaps even the third time. However, he failed to understand why the authorities would handle such allegations with similar gravity on their twentieth submission, as had been the case in his instance. Neither did he understand that when his ex-wife alleged in court that the children had become "mentally impaired" from living with him, this was never commented on in the court's reasoning, nor in the judgment:

Informant: "It's as if she never made the allegations. They never commented on it. They never mentioned that she actually said that at one point. So when they write 'counsel argues that [...]', they never include that stuff. I think that's a bit weird. It's as if she can do 
whatever she feels like, and then we pretend as if it never happened. And I'm left not knowing how significant they consider it to be [...] when they make their decision. They might think [...] 'Oh well, better safe than sorry' [...] Or that 'he's probably not easy to deal with."”

He found it difficult to understand how his ex-wife, as far as he was concerned, could say "whatever she felt like" in court without anybody bothering to query her. He felt that the family conflict to which he had been a party, had not been given a true hearing, but that the case had been handled purely as a matter of routine, without anybody really looking into the details. He believed that in the opinion of the court:

Informant: "[...] nobody was ever harmed by living with their mother for a year or so, until the case can be properly assessed. If mum has a poor relationship with dad, then it's better for the kids not to stay in touch with him [...] I feel that [...] nothing receives serious attention, and that even the wildest allegations are accepted."

The mother having a "poor relationship" with the father has been used as grounds for refusing visitation rights for the father. In one of the cases that Skjørten refers to, the father was refused visitation rights because:

"The mother's anxiety is considered to be a response to the father's behaviour. Contact between the father and the children may serve to sustain this anxiety, and may therefore affect the mother's ability to provide care. By refusing the father visitation rights, at least for a period, the court hoped to give the mother breathing space to deal with her anxiety." (Skjørten 2004:156)

Acceptance does not necessarily mean that the court believes everything women say. But the informant's impression was that they would allow allegations to go undisputed, and that they therefore might have an impact on the outcome of the case. He was also convinced that if they swapped roles, and he had maintained that the children were mentally impaired from living with their mother, or he had said that the children were suffering from diseases that no doctor would confirm, then it would have been mentioned in the grounds given for the judgement that he was making horrific allegations about his children and his wife. According to Philip 
Cook the burden of proof appears to be higher for men than for women in the same situation (Cook 1997:83). The informant argues in line with Cook, and he never dared query "the wildest allegations" in court for fear that this would have further reduced his chances of securing visitation rights. He refrained from querying his ex-wife's allegations in order to ensure that the court would at least consider him a non-vengeful and credible person.

\section{CONCLUSION}

In incidents reported from encounters with the child protection agency, the family support agency and the judiciary, the level of trust in the authorities is low, which is supported by Swedish research on intimate partner violence against men (Selin 2009:36). The informants stated that many of the allegations put forward by their ex-partners were never queried, and that "clearly unreasonable assertions" were ignored. The informants alleged that women often need not produce evidence in domestic cases; they need only come up with allegations, as the support agencies have a high level of confidence in women's versions of events. This perception may indicate that the high-level of discretion employed in child custody cases constitutes a challenge. ${ }^{18}$

The informants in this study reacted to a "horrifically unfair system", as one of the men put it. Obviously, this does not reflect how all men in Norway are treated in family cases. It is not correct - as some of the men in this study maintain - that the authorities have complete trust in all women's version of events. Yngvil Grøvdal shows in her thesis that women, in order to be credible in court, need to be credible victims. Everything from the way they dress and talk to the tenor of their narratives must appear to be

\footnotetext{
18 This challenge is pointed out by Kristin Skjørten: "It is reasonable to suspect that discretion will lead to a certain degree of variation between judges". The introduction to Official Norwegian Report (NOU) 1998:17 points out on p. 16 that: "In child custody cases a great deal of discretion is employed with respect to the application of law as well as in considering the factual aspects; the values held by the decision-maker may therefore influence the outcome to a greater extent than in civil cases" (Skjørten 2004:151, my translation).
} 
credible and they need to fit into the "victim" category (Grøvdal 2012:323 ff.; see also Ekström 2002).

The experiences of these specific male informants do not fit into a wellknown "victim" category. This helps boost their perception of Norwegian officials, that men suffer discrimination on account of gender in family cases in general, and in intimate partner violence and child custody cases in particular, because public authorities subscribe to traditional perceptions of gender, parenthood, masculinity and violence. The informants' narratives talk of bitterness, obviously towards the women, but to an even greater extent towards the authorities and the state, which is meant to safeguard both parties, but which according to the informants provide much stronger safeguards for women, thus prolonging the abuse suffered by men beyond the break-up of the relationship. ${ }^{19}$

The notion of cultural script may be used in a number of different settings. The combination of a traditional assumption on the one hand - that the mother is generally the best parent - and a more radical notion on the other - that women enjoy a particularly strong position in society - was considered by some of the informants to be "typically Norwegian" or to reflect a "Norwegian mindset". They claimed that Norway has little to offer men in their situation and that they are doomed to failure in virtually any battle over the family. First, the fathers of small children who have been embroiled in a family conflict, infer that what is "best for the child" is often considered to be subordinate to what is "best for the mother" (see also Holter 2003:167). Furthermore, the men find that women strategically exploit their virtually "self-evident" role as the victim in family cases. A woman's power in this situation may be interpreted as reverse gender bias, where women, who are conventionally viewed as subordinate, make

19 These views on Norwegian government authorities are similar to the criticism voiced by other men. Examples include the blogger Eivind Berge and others in the manosphere who claim that Norway is a feminist state, where boys and men have no opportunities (see e.g. Olsen 2011). But whilst Berge and others aim their criticism at Norwegian public authorities in general, with their opposition to the Purchase of Sexual Services Act at the crux of their argument, the informants in this study restrict their criticism to family law in general and to child custody and visitation proceedings in particular. 
use of their gender as an empowerment tool (cf. Lopez 2007:30, 89-90). Breaking the norms of gendered behaviour or not following a traditional cultural script may, in some instances, give rise to scepticism or disbelief, for example among family support and child protection officers, or in the judiciary. This gives rise to the idea that support agencies effectively "prolong the abuse" through their stereotypical perceptions of men. In this way, cultural scripts as a concept sheds light on the complex issue of men who in some way or another break with the norms of gendered behaviour, for example the limited group of men who are exposed to intimate partner violence, and in specific situations, i.e. this limited group's encounters with the judiciary and family support and child protection agencies during difficult family conflicts.

In a simple cultural script for family conflicts women tend to be seen as defenceless victims while men are considered potential perpetrators of intimate partner violence and even abusers of their own children. This script will exclude behaviour that fails to comply with the norms of gendered behaviour, such as crossovers. A woman acting as a manipulative strategist and abuser, and a man taking on the role of a victim of intimate partner violence, will both tend to be excluded from any such script as respectively non-feminine and non-masculine - the concepts are not recognised and cannot fit in with traditional perceptions..$^{20} \mathrm{~A}$ cultural script of women as victims and men as abusers, may cause some support workers to side with the woman, which in turn reproduces certain types of cultural scripts in which narratives of masculinity and femininity, supported by the media, are rather inflexible and conservative. Such a cultural script will exclude what fails to comply. A male victim of intimate partner violence appears implausible and unbelievable - and so his unconventional voice tends to be excluded and stigmatized.

20 Sidsel Natland points to similar exclusions in her thesis about young girls who batter other girls of the same age. According to her, the dominant discourse about violence provides a link between violence and masculinity. This discource is generated by the disregard for other ways of understanding the link between gender and violence (Natland 2006:215; see also Kongstad 2008:54). 


\section{REFERENCES}

ALSAKER, Kjersti. 2008. Quality of life among women who have experienced intimate partner violence. A one year follow-up study among women at Norwegian women's shelters. Doktoravhandling. Bergen: Universitetet of Bergen.

ALVER, Bente Gullveig \& Ørjar ØYEN. 1997. Forskningsetikk i forskerhverdag. Vurderinger og praksis. Oslo: Tano Aschehoug.

ALVER, Bente Gullveig, Tove Ingebjørg FJELL \& Ørjar ØYEN, eds. 2007. Research Ethics in Studies of Culture and Social Life. Helsinki: Suomalainen Tiedeakatemia.

AMUNDSEN, Elin, Inger BRAATHEN, Hilde FORS, Sissel GREBSTAD, Edel HILDRE, Anne Cathrine JOHNSEN \& Else Marie SPETALEN. 1981. Privatlivets fred. Ei bok om kvinnemishandling. Oslo: Pax Forlag.

BAKER, Phyllis L. 1997. “And I went back to him: Battered Women's Lack of Choices and Loss of Control”. Journal of Contemporary Ethnography 26/1:55-74. DOI: $10.1177 / 089124197026001003$

BREIVIK, Fritz Leo og Kate MEVIK. 2012. Barnefordeling $i$ domstolen. Når barnets beste blir barnets verste. Oslo, Universitetsforlaget.

COOK, Philip W. 1997. Abused Men. The Hidden Side of Domestic Violence. London, Praeger.

EKSTRÖM, Simon. 2002. Trovärdighet och ovärdighet : rättsapparatens hanterande av kvinnors anmälan av våldtäktsbrott, Stockholm 1946-1950. Doktoravhandling. Stockholm: Gidlund.

FJELL, Tove Ingebjørg. 2012. “'Women are Free to Rampage as Much as They Like...'. About Men who Suffer Intimate Partner Violence at the Hands of Female Partners." Ethnologia Scandinavica 42:121-130.

FJELL, Tove Ingebjørg. 2013. Den usynliggjorte volden. Om men som utsettes for partnervold fra kvinner. Trondheim: Akademika forlag.

FJELL, Tove Ingebjørg 2014. "Sterke kvinner - svake menn. Partnervold og humor." Tidsskrift for kjønnsforskning 3/4:302-314.

FLANZER, Jerry P. 2005. "Alcohol and Other Drugs Are Key Causal Agents of Violence”. In Current Controversies on Family Violence, eds. Donileen R. Loseke, Richard J. Gelles, Mary M. Cavanaugh. London: SAGE Publications, 163-173.

GRØVDAL, Yngvil. 2012. En vellykket sak? Kvinner utsatt for mishandling møter strafferettsapparatet. $\mathrm{PhD}$-avhandling, Det juridiske fakultet. Oslo: Universitetet i Oslo.

HAALAND, Thomas, Sten-Erik CLAUSEN \& Berit SCHEI, eds. 2005. Vold i parforhold - ulike perspektiver. Resultater fra den første landsdekkende undersøkelsen i Norge. Oslo: NIBR. 
HANSEN, Kasper Bisp. 2012. Vold begået af kvinder. En analyse af udviklingen. Det Kriminalpræventive Råd. Glostrup. http:/www.dkr.dk/sites/default/files/ Kvinder\%20der\%20begår\%20vold.pdf (Accessed: 5 June 2012).

HELWEG-LARSEN, Karin \& Marie Louise FREDERIKSEN. 2008. Vold mod moend $i$ Danmark. Omfang og karakter - 2008. København: Statens Institut for Folkesundhed, Syddansk Universitet.

HJEMMEN, Arne, Odd Steffen DALGARD \& Sidsel GRAFF-IVERSEN. 2002. "Volden som rammer kvinner og volden som rammer menn - to ulike verdener? Resultater fra anonym spørreundersøkelse blant 40-42-åringer i 1990-1994 i Akershus og Buskerud”. Norsk Epidemiologi 12/3:275-280.

HOLTER, Øystein Gullvåg. 2003. Can men do it? Men and gender equality - the Nordic experience. TemaNord 510. København: Nordisk ministerråd.

HYDÉN, Margareta. 1995. Kvinnomisshandel inom äktenskapet. Mellan det omöjliga och det möjliga. Malmø: Liber Utbildning.

JENSEN, An-Magritt. 2003. "Flere barn bor med far - mot et vendepunkt?" Statistisk sentralbyrå. Frigitt 20. juni. http://www.ssb.no/ssp/utg/200303/01/ (Accessed: 12 December 2012)

KONGSTAD, Annalise. 2008. “Bagatelagtige forhold vedrørende tidligere karester”. Om piger og vold. Det juridiske fakultet. København: Københavns universitet.

KVALE, Steinar. 1995. “Om tolkning af kvalitative forskningsinterviews”. In Artikler om Interviews. Jette Fog \& Steinar Kvale. Aarhus: Aarhus universitet, 151-162.

LOPEZ, Gro Saltnes. 2007. Minoritetsperspektiver på norsk familievern. Klienters erfaringer fra møtet med familievernkontoret. Rapport 9. Oslo: NOVA.

LUNDGREN, Eva. 2002. Captured queen. Men's Violence in "equal" Sweden - a prevalence study. Umeå, Brottsoffermyndigheten Fritzes offentliga publikationer.

MOXNES, Kari. 2001. "Felles foreldreskap etter skilsmisse." In Skilsmissens mange ansikter. Om barns og foreldres erfaringer med skilsmisse, eds. Kari Moxnes, Inge Kvaran, Hjørdis Kaul \& Irene Levin. Kristiansand: Høyskoleforlaget, 105-119.

NATLAND, Sidsel 2006. Volden, horen og vennskapet. En kulturanalytisk studie av unge jenter som utøvere av vold. Doktoravhandling. Bergen: Universitetet i Bergen.

NILSSON, Gabriella 2009. Könsmakt eller häxjakt? Antagonistiska föreställningar om mäns våld mot kvinnor. Doktoravhandling i etnologi. Lund: Lunds universitet.

PAPE, Hilde 2003. "Vold og krenkelser i unge menneskers parforhold". Tidsskrift for Den norske legeforening 123: 2016-2020.

PAPE, Hilde 2011. «Unge kvinners vold mot partner.» Tidsskrift for Den norske legeforening, 131: 1994-1997.

PAPE, Hilde \& Kari STEFANSEN, eds. 2004. Den skjulte volden? En undersøkelse av Oslobefolkningens utsatthet for trusler, vold og seksuelle overgrep. Rapport nr. 1. Nasjonalt kunnskapssenter om vold og traumatisk stress. Oslo: Universitetet i Oslo. 
PIZZEY, Erin 1980. Scream Quietly or the Neighbours will Hear. London: Pelican Books.

PLAUBORG, Rikke \& Karin HELWEG-LARSEN. 2012. Partnervold mod mond $i$ Danmark. København: Statens Institut for Folkesundhed, Syddansk Universitet. Udarbeidet for Ministeriet for Ligestilling og Kirke og Social- og Integrationsministeriet.

PRIPP, Oscar. 2009. (1999). "Reflektion och etik”. In Etnologiskt fältarbete, eds. Lars Kaijser \& Magnus Öhlander. Lund: Studentlitteratur, 41-54.

REFORM 2009. Ressurssenter for menn. www.reform.no (Accessed: 23 May 2015).

RESEARCH ETHICS COMMITTEES (Den nasjonale forskningsetiske komité for samfunnsvitenskap og humaniora). 2010. Forskningsetiske retningslinjer. http:// www.etikkom.no/Forskningsetikk/Etiske-retningslinjer/Samfunnsvitenskap-jusog-humaniora/ (Accessed: 23 May 2015).

SELIN, Klara Hradilova, 2009. Våld mot kvinnor och män i nära relationer. Våldets karaktär och offrens erfarenheter av kontakter med rättsväsendet. Rapport 12, Brå - centrum för kunskap om brott och åtgärder mot brott. Stockholm: BRÅ.

SKJØRTEN, Krisin. 2004. "Forståelser av overgrep i barnefordelingssaker". Tidsskrift for familierett, arverett og barnevernsrettslige spørsmål 3/4:150-170.

SKJØRTEN, Kristin. 2005. Samlivsbrudd og barnefordeling. En studie av lagmannsrettsdommer. Oslo: Gyldendal.

SOGN, Hanne \& Ole Kristian HJEMDAL. 2010. Vold mot menn i ncere relasjoner. Kunnskapsgjennomgang og rapport fra et pilotprosjekt. Oslo: Nasjonalt kunnskapssenter om vold og traumatisk stress.

STAHL, Sandra Dolby. 1977. "The Oral Personal Narrative in Its Generic Context." Fabula 18 1/2: 18-39. DOI: 10.1515/fabl.1977.18.1.18

STRAUS, Murray A. 2005. “Women's Violence Towards Men Is a Serious Problem”. In Current Controversies on Family Violence, eds. Donileen R. Loseke, Richard J. Gelles, Mary M. Cacanaugh. London: SAGE Publications, 55-77.

SÆTRE, Aina Helen. 2004. Undersøkelsen av samvaer og bidrag 2002. Dokumentasjonsog tabellrapport. Statistisk sentralbyrå. Notater nr. 26. http://www.ssb.no/ emner/02/01/20/notat_200426/notat_200426.pdf (Accessed: 12 December 2012).

VALVO, Brita Holm 1981. Du skal ikke slå ... Om kvinnemishandling og krisesentra. Oslo, Universitetsforlaget. 


\section{MEDIA REFERENCES}

MJELVA, Hans K. \& Trond NYGARD-STURE. 2011. “-Ville heller ha vore skulda for massemord.” Bergens Tidende Magasinet. April, 9.

OLSEN, Maren Næss. 2011. "Mann over bord”. Morgenbladet, December 15. http:// morgenbladet.no/samfunn/2011/mann_over_bord\#.UZITZuBWhBE (Accessed: 14 May 2013).

\section{REPORTS}

KRIPOS 2014. National homicide statistics. https://www.politi.no/vedlegg/lokale vedlegg/kripos/Vedlegg_2827.pdf(Accessed 12 October 2015).

REPORT TO THE STORTING no. 8 (2008-2009). Men, male roles and gender equality. Oslo: The Ministry of Children, Equality and Social Inclusion. https://www. regjeringen.no/en/dokumenter/report-no.-8-to-the-storting-2008-2009/id539104/ (Accessed: 12 March 2013).

SAVE THE CHILDREN (Redd barna) 1993. Barnekonvensjonen. Rettigheter for barn $i$ Norge. Oslo, Tano.

STATISTICS NORWAY 2010. Dette er Kari og Ola. Kvinner og menn i Norge. Oslo: SSB. http://www.ssb.no/befolkning/artikler-og-publikasjoner/_attachment/39417? ts $=132 \mathrm{af} 42 \mathrm{ef} 40(7$ October 2015$)$.

Tove Ingebjørg Fjell

\section{DISKRIMINACIJA MUŠKARACA? PRIČE O TRADICIONALNIM RAZUMIJEVANJIMA RODA}

Ovaj članak razmatra iskaze muškaraca koji tvrde da su bili izloženi nasilju koje su počinile njihove partnerice ili supruge, njihova iskustva s državnim ustanovama koje nude pomoć, probleme do kojih dolazi zbog očekivanja djelatnika koji pružaju pomoć od muškaraca, te načine na koje rod utječe na komunikaciju između muškaraca i ustanova koje nude pomoć. Koncept kulturnog pisma ključan je dio ove analize.

Ključne riječi: muškost, rod, skrb nad djecom, nasilje počinjeno od bliskog partnera 
